\title{
Effect of water flow on the photosynthesis of three marine macrophytes from a fringing-reef lagoon
}

\author{
Susana Enríquez* , Aimee Rodríguez-Román \\ Laboratorio de Fotobiología, Unidad Académica Puerto Morelos, Universidad Nacional Autónoma de México \\ (ICML-UNAM), Apdo. Postal 1152, 77500 Cancun, Mexico
}

\begin{abstract}
We studied the effect of water flow on the reduction of the photosynthetic electron transport rates (ETR) of the seagrass Thalassia testudinum and the brown algae Lobophora variegata and Padina sanctae-crucis. The main objective of this study was to contribute to the understanding of the magnitude of carbon limitation in a sheltered, shallow coral reef environment, while improving the use of the fluorescence technique. The results confirm that photosynthesis, in the 3 species, is sink limited at normal seawater $\mathrm{pH}$. Considering that the actinic light intensity chosen for the experimental design was close to saturation irradiance for the 3 species, stronger ETR declines are expected under larger carbon requirements at supersaturating irradiance. The results suggest that photosynthesis may be strongly carbon limited in sheltered coral reef environments. Nevertheless, pharmacological experiments revealed the occurrence of carbon concentration mechanisms (CCM) related to: (1) the external presence of the enzyme carbonic anhydrase under very low hydrodynamics, when the diffusive boundary layers stabilize and enzyme losses are minimal ( $L$. variegata and T. testudinum) and (2) the ability to take up $\mathrm{HCO}_{3}^{-}$(T. testudinum and P. sanctae-crucis). The possibility that the capacity to calcify may be associated with the CCM of P. sanctae-crucis needs further testing. These results suggest that photosynthetic organisms adapted to coral reef systems, where calm, cloudless days with minimal water turbulence and maximum light penetration are common, have developed efficient CCMs. The study also supports the utility of the fluorescence technique for the analysis of the photosynthetic response to hydrodynamics within the limits imposed by the linearity between oxygen-based and fluorescence-based photosynthesis determinations. It also emphasizes the importance of light absorption determinations for accurate estimations of ETR values.
\end{abstract}

KEY WORDS: Brown algae $\cdot$ Carbon limitation $\cdot$ Carbon concentration mechanisms $\cdot \mathrm{CCM} \cdot$ Coral reef $\cdot$ Electron transport rate $\cdot$ ETR $\cdot$ Fluorescence $\cdot$ Thalassia testudinum $\cdot$ Water

\section{INTRODUCTION}

Photosynthesis in aquatic environments is exposed to stronger limitation by carbon availability than in terrestrial ecosystems (Madsen \& Sand-Jensen 1991). Dense biomass stands in aquatic communities have photosynthetic rates that are a third lower than those in terrestrial communities. Photosynthesis in water also exhibits larger reductions for similar declines in inorganic carbon availability (Krause-Jensen \& SandJensen 1998). These differences are explicable by the lower diffusion rates of $\mathrm{CO}_{2}$ and $\mathrm{HCO}_{3}^{-}$(4 to 5 orders of magnitude) in water than in air (Raven 1984). The importance of carbon limitation in the reduction of marine primary production has not yet been fully evaluated, nor has the diverse capacity of photosynthetic organisms to counterbalance this effect. Marine environments are characterized by high total alkalinity values. However, the high concentrations of inorganic carbon dissolved in seawater do not necessarily reflect high carbon availability for photosynthesis, given that the concentration of $\mathrm{CO}_{2}$, which is the most accessible inorganic carbon form for photosynthesis, is between 10.2 and $18.8 \mu \mathrm{M}$ in the temperature range from 5 to 
$25^{\circ} \mathrm{C}$ and under the current atmospheric equilibrium (Raven 1984). Under these conditions, the $\mathrm{HCO}_{3}{ }^{-}$concentration has a relatively constant value of $2 \mathrm{mM}$. Thus, most of the inorganic carbon available for photosynthesis in the marine environment is in an ionic form not directly accessible for photosynthesis.

According to Fick's law, carbon fluxes are directly associated with the diffusion coefficient and with differences in the inorganic carbon concentration between both external and internal tissue environments (Raven \& Richardson 1986), but inversely associated with the thickness of the boundary layer surrounding the tissue. The boundary layer is an important molecular diffusion barrier for carbon incorporation in photosynthesis (Kirk 1994). The resistance imposed by the boundary layer has been shown to be larger than that of the cuticle, cell wall, and cell and chloroplast membranes (Larkum et al. 1989). Boundary layer thickness is variable and dependent on: (1) the size and shape of the photosynthetic surfaces (Nowell \& Jumars 1984), in particular surface roughness and/or the presence of hairs or any other protruding structures that may generate water turbulence or stabilize a laminar flow surrounding the tissue, and (2) the intensity and directionality of the water flow (Wheeler 1980, MacFarlane \& Raven 1989). Hence, hydrodynamism appears to be a primary factor that should be considered in the evaluation of the magnitude of carbon limitation of photosynthesis in the aquatic environment.

The development of different mechanisms, which promote intracellular accumulation of $\mathrm{CO}_{2}$ (carbon concentration mechanism, CCM) allow photosynthetic organisms to reduce the effect of carbon limitation on photosynthesis. In many aquatic primary producers, CCM activity has been associated with the direct or indirect use of $\mathrm{HCO}_{3}{ }^{-}$(Smith \& Bidwell 1989, Maberly 1990, Bjørk et al. 1992, James \& Larkum 1996, Beer \& Rehnberg 1997, Invers et al. 1999, 2001). The capacity to take up $\mathrm{HCO}_{3}{ }^{-}$has been detected in several fresh- and brackish-water macrophytes and in marine macrophytes (Borowitzka 1982, Drechsler \& Beer 1991). Also, the activity of the enzyme carbonic anhydrase (CA) has been broadly documented (Borowitzka 1982, Giordano \& Maberly 1989, James \& Larkum 1996, Beer \& Rehnberg 1997, Bjørk et al. 1997, Invers et al. 1999), although its location and relative importance as a CCM is still controversial. $\beta$-carboxylation and enzymes such as phosphoenol pyruvate carboxylase (PEPC), phosphoenol pyruvate carboxykinase (PEPCK), pyruvate carboxylase (PC), acetyl CoA carboxylase (ACoC), etc., which facilitate metabolic alternatives to the inorganic carbon carboxylation, make an important contribution to the CCMs (Bowes 1985, Raven \& Osmond 1992). These mechanisms appear in taxonomically distant organisms that broadly differ in size and shape.
Marine life is currently experiencing important changes associated with global climate change. However, few data are available on the physiological responses of marine macrophytes to the predicted increases in water temperature, $\mathrm{CO}_{2}$ availability and UV-B radiation (e.g. Beer \& Koch 1996, Zimmerman et al. 1997). In the present paper, we study the magnitude of carbon limitation on the photosynthesis of the seagrass Thalassia testudinum and the brown algae Lobophora variegata and Padina sanctae-crucis. The effect of water flow was examined on the reduction of the photosynthetic electron transport rates of these 3 species of benthic coral reef primary producers. The main objective of this study was to contribute to the understanding of the magnitude of carbon limitation in a sheltered, shallow coral reef environment, while improving the use of the fluorescence technique in the analysis of the photosynthetic response. We chose these 3 species because in the reef-lagoon studied (Puerto Morales, Mexico), T. testudinum is the dominant species, $L$. variegata is increasing in abundance, while the presence of $P$. sanctae-crucis has been reduced to a seasonal or rare species. In addition, we expected to obtain contrasting photosynthetic responses to water flow reduction and in the possible CCMs involved. The 2 brown algae have a similar shape, but P. sanctae-crucis also has the capacity to calcify, similar to an important fraction of the coral reef primary producers. The quantification of interspecific differences in the photosynthetic sensitivity to water flow reductions and in the diversity of their functional CCMs may contribute to highlighting ecological differences and spacio-temporal variability in the photosynthetic performance, growth and abundance of the small, but representative, group of primary producers of the coral reef system examined in the present study. It may also provide useful information in identifying the differential sensitivity of these species to global changes. To improve our understanding of the possible CCMs involved, pharmacological experiments were also carried out.

\section{MATERIALS AND METHODS}

The species examined were collected between 2 and $3 \mathrm{~m}$ depth in a fringing-reef lagoon (Puerto Morelos, Yucatan peninsula, Mexico) between August and September 2001, and acclimated in tanks with running filtered seawater pumped directly from the reef lagoon to the aquarium facility at the station of the Universidad Nacional Autónoma de México (UNAM) in Puerto Morelos (UAPM). Organisms were maintained for $1 \mathrm{~d}$ in the tanks before being used in the experiments. A subsample of Thalassia testudinum shoots was main- 
tained for $6 \mathrm{~d}$, and a second experimental determination was performed on this group of leaves following the same protocol used for the $1 \mathrm{~d}$ old samples. Initial maximum photochemical efficiencies $\left(F_{\mathrm{v}} / F_{\mathrm{m}}\right)$ of darkacclimated tissues were $0.736 \pm 0.003$ for $T$. testudinum, $0.721 \pm 0.011$ for Lobophora variegata and 0.711 \pm 0.001 for Padina sanctae-crucis. Prior to the experimental work, the organisms were submerged for $4 \mathrm{~h}$ in a bath with water circulation provided by means of a submersible pump, at a constant temperature of $29^{\circ} \mathrm{C}$, and illuminated with a halogen white-lamp delivering $330 \mu \mathrm{mol}$ quanta $\mathrm{m}^{-2} \mathrm{~s}^{-1}$ to induce photosynthesis under comparable conditions. Photosynthesis induction was required to counterbalance the dark inhibition of the enzyme ribulose-1,5-bisphosphate carboxylase/oxygenase (Rubisco) (Gutteridge et al. 1986). The effective photochemical efficiency $\left(\Delta F / F_{m}{ }^{\prime}\right)$ of the tissue after photosynthesis induction was, on average, $0.589 \pm 0.003$ for the $1 \mathrm{~d}$ tank-acclimated T. testudinum leaves, $0.704 \pm 0.001$ for the seagrass leaves maintained for $6 \mathrm{~d}$ in the tanks, $0.450 \pm 0.004$ for L. variegata and $0.614 \pm 0.022$ for $P$. sanctae-crucis. After photosynthesis induction, samples were placed in an acrylic chamber, which was especially designed to determine the effect of water flow on photosynthesis. The acrylic chamber allowed the photosynthetic tissue to be maintained under variable controlled laminar flow while connected to the fiberoptics of a PAM 101/102/103 fluorometer (Walz) (Fig. 1). The chamber consisted of

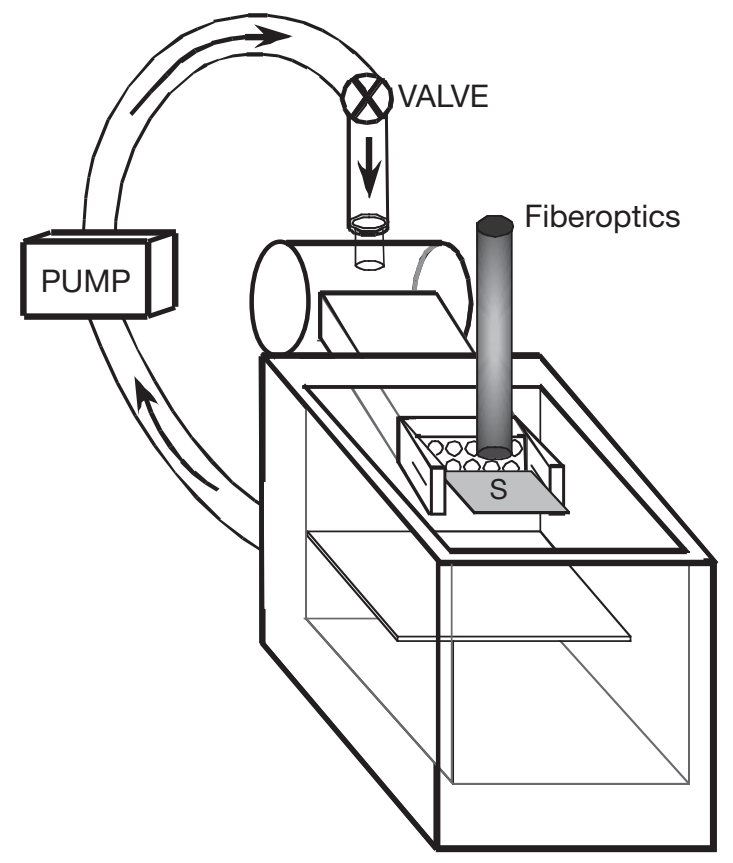

Fig. 1. Diagrammatic representation of the experimental acrylic flow chamber. The gray surface at the water entrance of the box illustrates the position of the photosynthetic tissue (S: sample) an $850 \mathrm{ml}$ open box (dimensions: $18 \times 11 \times 9 \mathrm{~cm}$ ) attached to an acrylic cylinder $(4.5 \mathrm{~cm}$ diameter and $7 \mathrm{~cm}$ long) through a rectangular structure $(8 \times 3.5 \mathrm{~cm})$ (Fig. 1). This structure was filled with drinking straws oriented in the direction of the flow, in order to induce a laminar flow at its exit. The total volume of the chamber was $950 \mathrm{ml}$.

Water flow was generated with a non-submersible pump (1.AA-MD, Little-Giant Pump Company) with magnetic impulsion, able to move $10.21 \mathrm{~min}^{-1}$. The water flow generated was laminar and homogeneous before reaching the site where the photosynthetic tissue was held. This conclusion was obtained after checking the water movement in this area using dye. We did not observe variation in the dye displacement along the mouth and/or the formation of eddies. The intensity of the water flow was regulated with a pinch valve (Flow-rite PV-4, Aldrich Chemical Company) with $10 \times 10$ control options (i.e. 10 main positions and 10 intermediate positions in between them). Water velocity was estimated by measuring the time required to fill a volume of $500 \mathrm{ml}$ with a $6 \mathrm{~mm}$ diameter tube connected to the cylindrical structure (Fig. 1) and corrected later for the $21.5 \mathrm{~cm}^{2}$ out-flow exit of the rectangular unit. According to these calculations, maximum flow was $5.3 \mathrm{~cm} \mathrm{~s}^{-1}$, which was in the range of a highenergy environment for Thalassia testudinum (Koch 1994) (although it represents a low energy environment for the SW Australian seagrass habitats; Keulen \& Borowitzka 2000). For the Puerto Morelos reef lagoon, the Hydrographic and Meteorology Service of the UAPM has registered an average $( \pm \mathrm{SD})$ value of 2 $\pm 1.4 \mathrm{~cm} \mathrm{~s}^{-1}$ in the central part of the lagoon (where the samples were collected) ranging between a maximum of 8.9 and a minimum of $0.08 \mathrm{~cm} \mathrm{~s}^{-1}$ (EscalanteMancera \& Ruíz-Rentería unpubl. data). These values were registered with an Acoustic Doppler Velocimeter (Argonaut-ADV, SonTek/YSI). The measurements were made at $2 \mathrm{~cm}$ from the sediment, using a $6 \mathrm{~mm}$ diameter $\times 9 \mathrm{~mm}$ high cylinder, and values were recorded every $5 \mathrm{~s}$ during $1 \mathrm{~h}$. Values correspond to the August to September period in the area.

For the experimental analysis, 5 experimental conditions were chosen according to the valve position. Water velocity was determined directly for each selected condition and resulted in maximal water flow of $5.3,2.44,1.2,0.46$ and $0 \mathrm{~cm} \mathrm{~s}^{-1}$. Two acrylic arms placed in parallel to the water entrance of the box held the photosynthetic tissue horizontally by means of a $1.5 \mathrm{~mm}$ slot (Fig. 1). The arms also served as the support for an acrylic holder, which allowed the fluorometer fiberoptics to be placed perpendicular to the tissue surface without touching the water and, thus, without interfering with the water flow. To isolate the area with laminar flow from the turbulence generated 
by the pump suction, the flow entrance was separated from the exit using a $13 \mathrm{~cm}$ long acrylic sheet that allowed $3 \mathrm{~cm}$ of free contact between both volumes (Fig. 1). The chamber was covered by a water jacket connected to a circulating bath with a controlled temperature system (RTE-100/RTE-101LP, Neslab Instruments).

The photosynthetic response to the changes in water flow was determined by monitoring the variation in the chlorophyll a fluorescence signal with a PAM 101/ 102/103 fluorometer (Walz) connected to a PDA-100 data-acquisition system (Walz). The actinic light was provided by a KL 1500 electronic lamp (Schoot Glaswerke) attached to the 5-arm fiberoptics of the fluorometer. The photosynthetic descriptor used was the electron transport rate (ETR) calculated from the variation in $\Delta F / F_{\mathrm{m}}$ ' following Genty et al. (1989). The variation in $\Delta F / F_{\mathrm{m}}$ ' was continuously registered every $1 \mathrm{~min}$ over a period of $1 \mathrm{~h}$ (Fig. 2). As $\Delta F / F_{\mathrm{m}}{ }^{\prime}$ did not reach steady-state after $1 \mathrm{~h}$ of incubation, this decline was better expressed by calculating the relative ETR
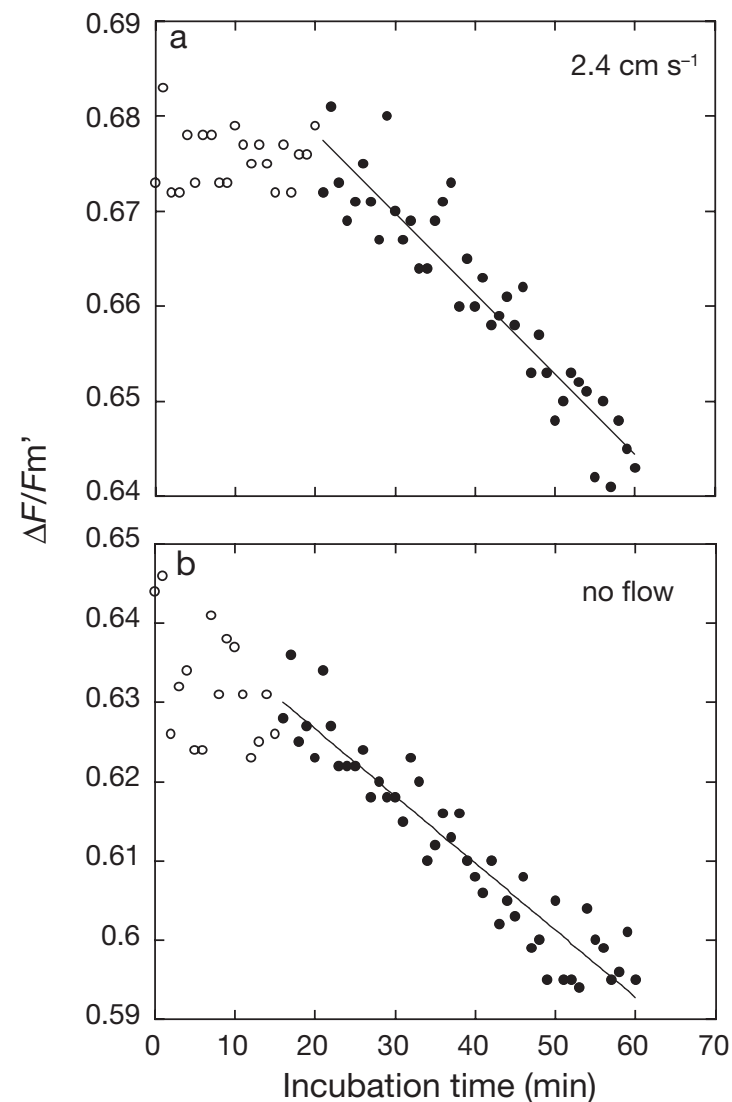

Fig. 2. Thalassia testudinum. Variation in the effective photochemical efficiency $\left(\Delta F / F_{\mathrm{m}}{ }^{\prime}\right)$ of leaves at: (a) $2.4 \mathrm{~cm} \mathrm{~s}^{-1}$ and (b) stagnant conditions $\left(0 \mathrm{~cm} \mathrm{~s}^{-1}\right)$, monitored every $1 \mathrm{~min}$. (Open circles: $\Delta F / F_{\mathrm{m}}{ }^{\prime}$ values excluded from the determination and obtained during the initial 15 to $20 \mathrm{~min}$; solid circles: other values obtained during the following 40 to $45 \mathrm{~min}$ used for the determination of the slope $[ \pm \mathrm{SE}]$ of the $\Delta F / F_{\mathrm{m}}{ }^{\prime}$ variation) reduction observed after $1 \mathrm{~h}$ of incubation. ETR values were calculated using the equation (Genty et al. 1989):

$$
\mathrm{ETR}=\mathrm{PAR} \times\left(\Delta F / F_{\mathrm{m}}{ }^{\prime}\right) \times 0.5 \times \text { Absorptance }
$$

where PAR is photosynthetically active radiation and Absorptance refers to the fraction of incident light absorbed by the photosynthetic surface (Kirk 1994). We first calculated the magnitude of the ETR reduction using:

$$
\begin{gathered}
\Delta \operatorname{ETR}\left(\mathrm{h}^{-1}\right)=\operatorname{PAR} \times \text { Absorptance } \times 0.5 \times\left[\left(\Delta F / F_{\mathrm{m}}{ }^{\prime}\right)_{0}-\right. \\
\text { Rate } \times(60 \mathrm{~min})]
\end{gathered}
$$

where $\left(\Delta F / F_{\mathrm{m}}{ }^{\prime}\right)_{0}$ is the initial value (after $4 \mathrm{~h}$ of photosynthesis induction) and Rate is the slope of a constant smooth reduction determined for each incubation. This value was then divided by the initial ETR value:

$$
\left[\mathrm{ETR}_{0}=\mathrm{PAR} \times \text { Absorptance } \times 0.5 \times\left(\Delta F / F_{\mathrm{m}}{ }^{\prime}\right)_{0}\right]
$$

The rate of $\Delta F / F_{\mathrm{m}}{ }^{\prime}$ change was obtained by fitting the values registered to a least-squares (LS) regression model. Data from the initial 15 to 20 min were excluded from the determination, as they were affected by the previous conditions. The slope $( \pm \mathrm{SE})$ of the $\Delta F / F_{\mathrm{m}}{ }^{\prime}$ variation was obtained from the values for the remaining 40 to 45 min (Fig. 2 illustrates the criteria used for each determination). The finding that no steady-state was achieved after $1 \mathrm{~h}$ of incubation under less optimal water-flow conditions is explained by the consideration that the laminar flow produced in the experimental chamber did not allow the formation of local equilibrium at the tissue surface, between the consumption and the supply of a limiting factor (i.e. inorganic carbon), for 2 reasons: (1) the volume of the experimental chamber was open to air and too large in relation to the activity of the tissue examined and (2) the water was homogenized every time it passed through the pump. Consequently, the observed reduction in $\Delta F / F_{\mathrm{m}}$ ' was the result of a continuous depletion in carbon supply, similar to the lightdark shifts used to determine respiration and photosynthesis rates with $\mathrm{O}_{2}$ microelectrodes (Revsbech \& Jørgensen 1983). Because carbon diffusion and carbon demands were maintained within similar values during the experiment (i.e. water temperature and actinic irradiance did not change), the variation observed in the rate of the $\Delta F / F_{\mathrm{m}}$ ' decline is associated with changes in the size of the boundary layer.

The experimental sequence was, in all cases, from maximum to minimum water flux. Average values were calculated on 4 determinations per tissue section, obtained from 4 different individuals. Thalassia testudinum leaves were collected from 2 different meadows: $2 \mathrm{~m}$ depth adjacent to the UAPM pier and $3 \mathrm{~m}$ depth in the meadow closest to the back-reef. We used the second youngest leaf. In total, 12 leaf sections from these 2 sites were examined, together with an addi- 
tional 4 leaves which were collected in the back-reef meadow and acclimated for $6 \mathrm{~d}$ in the UAPM tanks under low water flow conditions.

Prior to determination of the effect of water flow on the photosynthesis of this group of macrophytes, possible interspecific differences in the magnitude of carbon limitation at seawater $\mathrm{pH}$ were examined using $5 \mathrm{pH}$ levels $(7,7.5,8,8.5,9)$. Artificial seawater was produced as ASP-8A medium (Blank 1987), excluding nutrient addition $\left(\mathrm{NH}_{4} \mathrm{NO}_{3}\right.$ and $\left.\mathrm{KH}_{2} \mathrm{PO}_{4}\right)$. $\mathrm{pH}$ levels were adjusted with $\mathrm{HCl}$ and $\mathrm{NaOH}$. Five tissue samples per species were submerged for $1 \mathrm{~h}$ in transparent $150 \mathrm{ml}$ bottles provided with magnetic stirring and illuminated with $330 \mu$ mol quanta $\mathrm{m}^{-2} \mathrm{~s}^{-1}$. After $1 \mathrm{~h}$, a fast photosynthetic response curve (photosynthesis, $P$ vs. irradiance, E) was determined using a PAM fluorometer (diving PAM, Walz), using 1 min of illumination per irradiance value. Measurements were made in a small tray that allowed leaf sections to remain submerged in the same medium, held with a magnetic clip attached to the fiberoptics.

Light absorption was determined spectrophotometrically following Enríquez (2005). Absorbance values (i.e. optical density, $D$ ) were determined between 380 and $750 \mathrm{~nm}$ with $1 \mathrm{~nm}$ resolution with an Aminco DW2 spectrophotometer controlled by an OLIS data collection system. Non-pigmented tissue was used as a reference to correct for non-pigment absorption. Absorptance $(A)$ was calculated using the equation: $A=1-$ $10^{-D}$. Absorptance values were further corrected by subtracting tissue reflectance $(R)\left(A=1-10^{-D}-R\right)$. Tissue reflectance was measured following Enríquez (2005). Reflectance spectra were also measured in the PAR range using a SpectraPro 300i spectrometer (Acton Research) attached to the miniature fiberoptics. Homogeneous illumination was provided by an incandescent light source placed $\sim 15 \mathrm{~cm}$ above the sample, making a $45^{\circ}$ angle. The reflected light was collected with a $2 \mathrm{~mm}$ diameter waveguide attached to the spectrometer. The detector waveguide was placed underwater, $1 \mathrm{~cm}$ away from the sample at a $45^{\circ}$ angle to the sample (a detailed description of this methodology is provided in Enríquez et al. 2005). The emission spectra of the actinic light sources utilized in this study were also determined for a final correction of the absorptance values. These measurements were performed using a 4800S Lifetime spectrofluorometer (SLM-Aminco), equipped with a red sensitive photo-multiplier tube (R955, Hamamatsu).

The appropriateness of the use of ETR as a descriptor of photosynthetic rates was checked on Thalassia testudinum by simultaneous determinations of fluorescence (ETR) and polarographic $\left(\mathrm{O}_{2}\right.$ evolution) values using a DW3 chamber (Hansatech Instruments) coupled to the 5-arm fiberoptics of the PAM 101/102/103 fluorometer (Walz).
To improve our understanding of the possible CCMs involved, pharmacological experiments were carried out. We used the external CA inhibitor acetazolamide (AZ or Diamox, N-[5-sulfamoyl-1,3,4-thiadiazol-2-yl] acetamide), the anion carrier inhibitor 4,48-diisothiocyanostilbene-2, 28-disulfonic acid (DIDS) and the $\mathrm{Ca}^{2+}$ channel blocker Verapamil. The 3 inhibitors were dissolved in dimethyl sulfoxide (DMSO) and diluted in filtered seawater $(0.45 \mu \mathrm{m}$, Millepore) to a volume proportion $(\mathrm{v} / \mathrm{v})$ of $<1 \%$. Treated tissue samples were submerged in $20 \mathrm{ml}$ of seawater with the extracellular AZ inhibitor. To facilitate the penetration of the inhibitors DIDS and Verapamil into the tissue, we produced a moderate vacuum with a $20 \mathrm{ml}$ syringe. The effect of the inhibitors on the effective photochemical efficiency $\left(\Delta F / F_{\mathrm{m}}{ }^{\prime}\right)$ was examined with the PAM 101/ 102/103 fluorometer (Walz) on 12 replicates per treatment of samples recently collected from the field $(<1 \mathrm{~h})$ at the peak irradiance period $(12: 00 \mathrm{~h})$. Prior to the inhibitor treatment, $\Delta F / F_{\mathrm{m}}$ ' was measured to estimate the initial control value. After infiltration, samples were exposed for $5 \mathrm{~min}$ to $300 \mu \mathrm{mol}$ quanta $\mathrm{m}^{-2} \mathrm{~s}^{-1}$ to examine the effect of the 3 inhibitors on $\Delta F / F_{\mathrm{m}}{ }^{\prime}$. An infiltration control with filtered seawater was also used to check the effect of the moderate vacuum on $\Delta F / F_{\mathrm{m}}$ ' (control treatment). To examine the effect of the 3 inhibitors on dark-adapted tissue, changes in $F_{\mathrm{v}} / F_{\mathrm{m}}$ were recorded the day after field collection of samples. Samples were left overnight with aerated seawater to allow for complete relaxation of Photosystem II (PSII). Prior to the inhibitor treatment, $F_{\mathrm{v}} / F_{\mathrm{m}}$ was recorded as an initial control of the darkness treatment. After the treatment, the samples were kept in darkness for 10 min and $F_{\mathrm{v}} / F_{\mathrm{m}}$ was recorded again.

The results are expressed as averages $( \pm \mathrm{SE})$. A 1-way ANOVA was used to test for significant differences among treatments. A 2-way ANOVA was used to test for significant differences in the interaction between $\mathrm{pH}$ treatments $(\mathrm{df}=4)$ and species $(\mathrm{df}=2)$. LS regression analysis was used to test the linearity of the association between ETR values and $\mathrm{O}_{2}$ evolution rates. Homogeneity of variance and normality were first determined, and log transformations were used when necessary. All of the statistical analyses were performed using SYSTAT software (Wilkinson 1989).

\section{RESULTS}

Light absorption spectra revealed, as expected, interspecific differences in pigment composition (Fig. 3a). The red part of the absorption spectra shows the absorption bands of chl $a$ and $b$ for the seagrass Thalassia testudinum (1) and the absorption bands of chl $a$ and $c$ for the 2 brown algae Lobophora variegata 

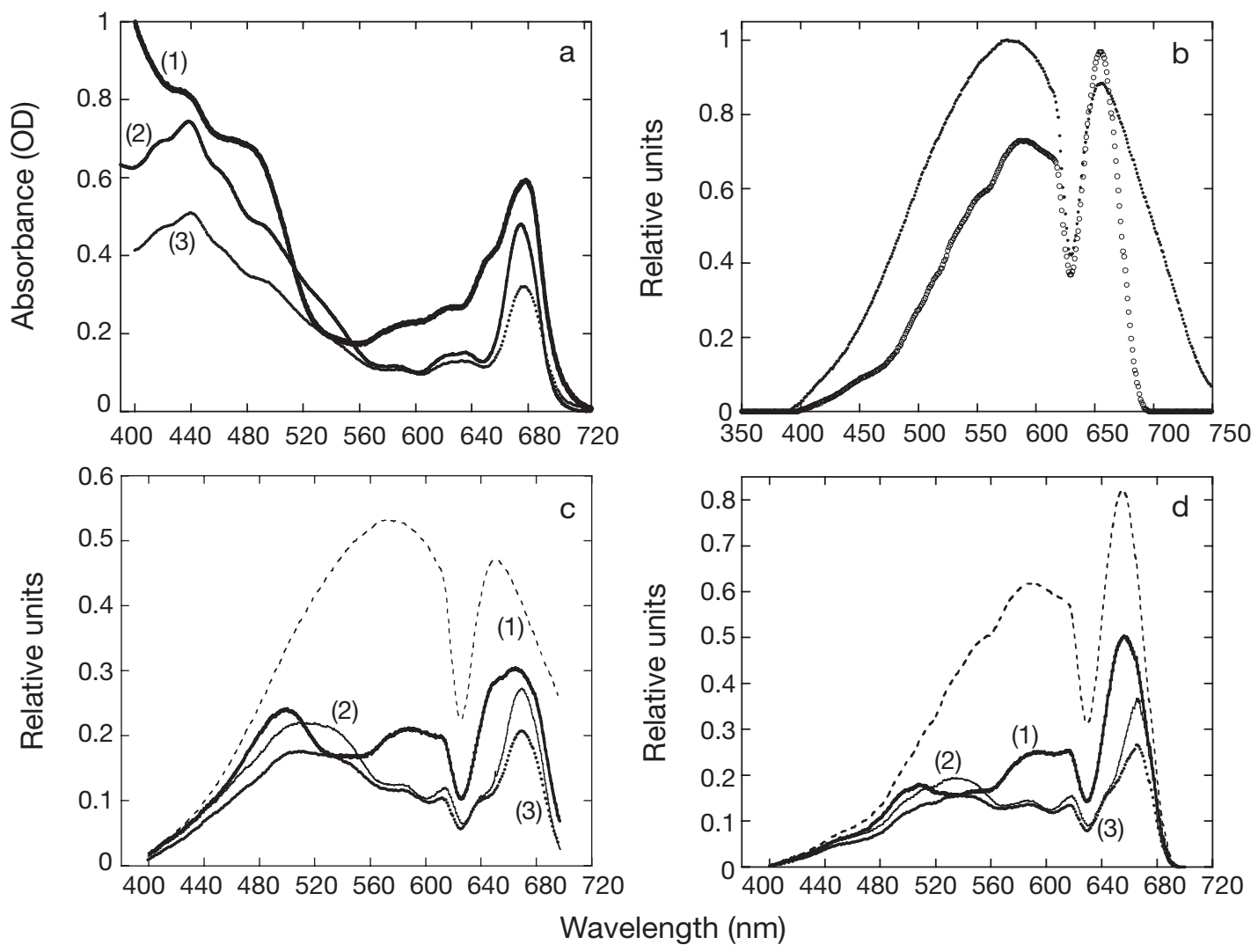

Fig. 3. Light-absorption spectra for (1) leaf segments of Thalassia testudinum, thalli of (2) Lobophora variegata and (3) Padina sanctae-crucis showing (a) spectroscopic determinations, (b) emission spectra of the lamps used as actinic light (KL 1500 electronic lamp, Schoot Glaswerke and diving PAM light, Walz), (c,d) uncorrected spectra for the actinic light of KL 1500 and diving PAM light, respectively. Dashed lines $(\mathrm{c}, \mathrm{d})$ represent both emission spectra

(2) and Padina sanctae-crucis (3) (Fig. 3a). They also revealed significant interspecific differences in tissue absorptance. T. testudinum leaves absorbed an average of $65 \pm 1.4 \%$ of the incident light, whereas $L$. variegata thalli absorbed $55 \pm 0.86 \%$ and $P$. sanctae-crucis showed the lowest absorptance $(41.8 \pm 2.3 \%)$. In this experimental approach 2 actinic light sources were used: (1) the KL 1500 electronic lamp (Schott Glaswerke) for the PAM 101/102/103 and (2) the diving PAM light source. The light spectrum of the first lamp showed relative lower emission in the 400 to $500 \mathrm{~nm}$ PAR range (Fig. 3b), which resulted in a significant reduction in the estimated absorptance. The diving PAM actinic light showed similar emission to the other lamp in the 400 to $500 \mathrm{~nm}$ range, but even lower emis-

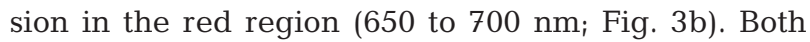
emission spectra are shown normalized to maximal emission (Fig. 3b). The absorptance values of the 3 species were corrected for both light emission spectra, and the new light absorption spectra are shown in Fig. 3c,d. For comparison, the emission spectra are also shown in different relative units (total integrated area $=100$ ). According to the new estimations, T. testu- dinum leaves absorbed $52 \%$ of the actinic light received by the light source of the PAM 101/102/103 and $50 \%$ of the diving PAM actinic light. The thalli of $L$. variegata and P. sanctae-crucis absorbed, respectively, 41.3 and $35 \%$ of the first light source and 37.4 and $31 \%$ of the second.

Fig. 4 illustrates the differences observed among species in the photosynthetic response (measured as ETRs) to increased irradiance and at different $\mathrm{pH}$ values. We found significant differences among species in the magnitude of the variation of the photosynthetic rates in subsaturating and supersaturating light (Figs. $4 \& 5 \mathrm{a}, \mathrm{b}$ ). At an irradiance value of $127 \mu \mathrm{mol}$ quanta $\mathrm{m}^{-2} \mathrm{~s}^{-1}$, the 3 species showed significant reductions in ETRs with respect to the maximum observed at $\mathrm{pH}=7.0(26,39$ and $13 \%$, respectively, for Thalassia testudinum, Lobophora variegata and Padina sanctaecrucis; Figs. 4 \& 5a). The ANOVA test showed significant differences among $\mathrm{pH}$ treatments $(\mathrm{p}<0.001)$ and among species $(p<0.001)$ in the ETR values at this irradiance, but no significant differences for the interaction (2-way ANOVA, $p>0.05)$. Only L. variegata showed a strong reduction (64\%) in ETR at supersatu- 

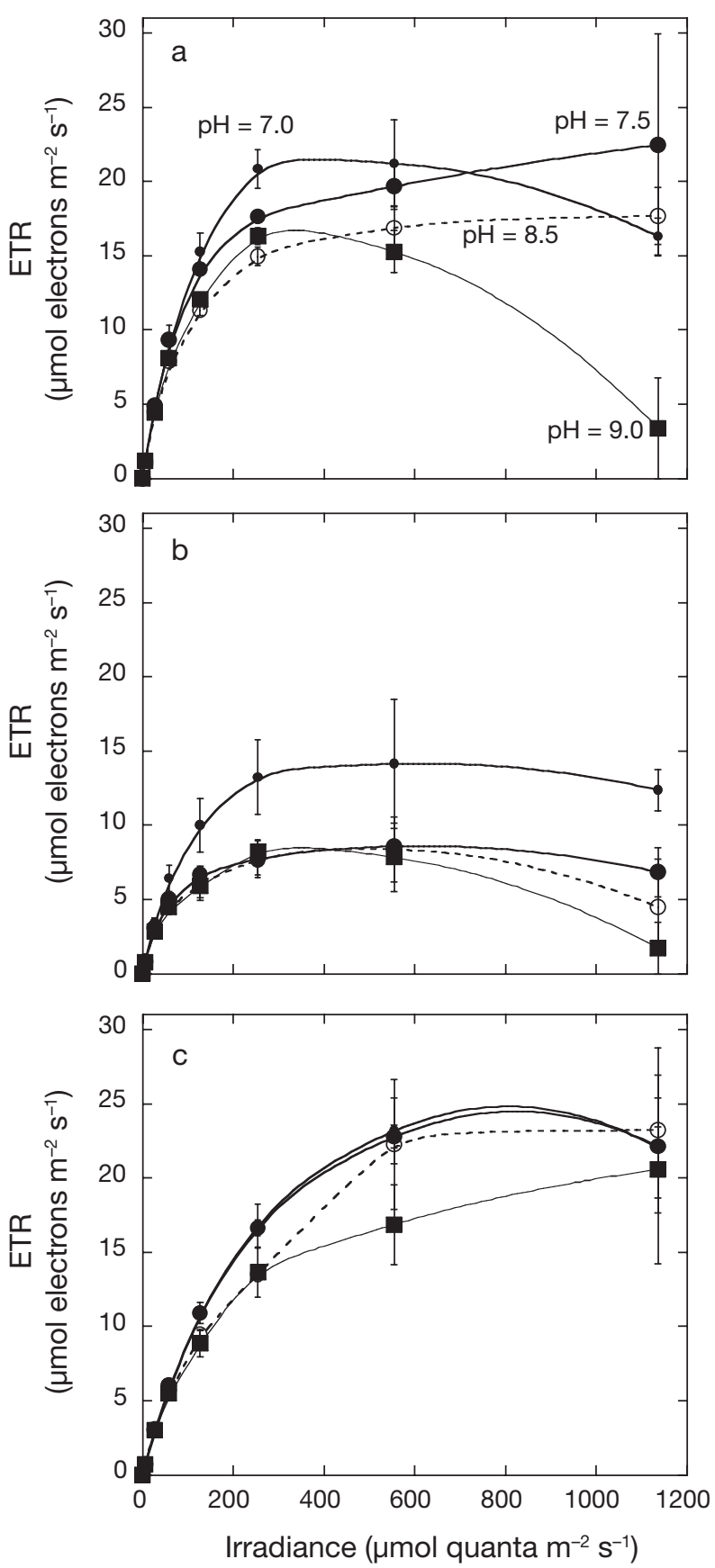

Fig. 4. Variation in the mean $( \pm \mathrm{SE})$ electron transport rate $\left(E T R ; \mu \mathrm{mol}\right.$ electrons $\mathrm{m}^{-2} \mathrm{~s}^{-1}$ ) as a function of irradiance ( $\mu \mathrm{mol}$ quanta $\mathrm{m}^{-2} \mathrm{~s}^{-1}$ ) and $\mathrm{pH}$ for: (a) Thalassia testudinum, (b) Lobophora variegata and (c) Padina sanctae-crucis. (•: $\mathrm{pH}=7$; - $\mathrm{pH}=7.5 ; \mathrm{O}: \mathrm{pH}=8.5 ; \mathbf{\square}: \mathrm{pH}=9$ ). For clarity, $\mathrm{pH}=8$ is not shown

rating irradiance $\left(1136 \mu \mathrm{mol}\right.$ quanta $\left.\mathrm{m}^{-2} \mathrm{~s}^{-1}\right)$, whereas the rates for $T$. testudinum and $P$. sanctae-crucis did not exhibit any significant change (ANOVA[pH] $\mathrm{p}<$ 0.001; ANOVA[species] $\mathrm{p}>0.1$; 2-way ANOVA[pH $\times$ species] $p>0.2$; Fig. 5a,b).
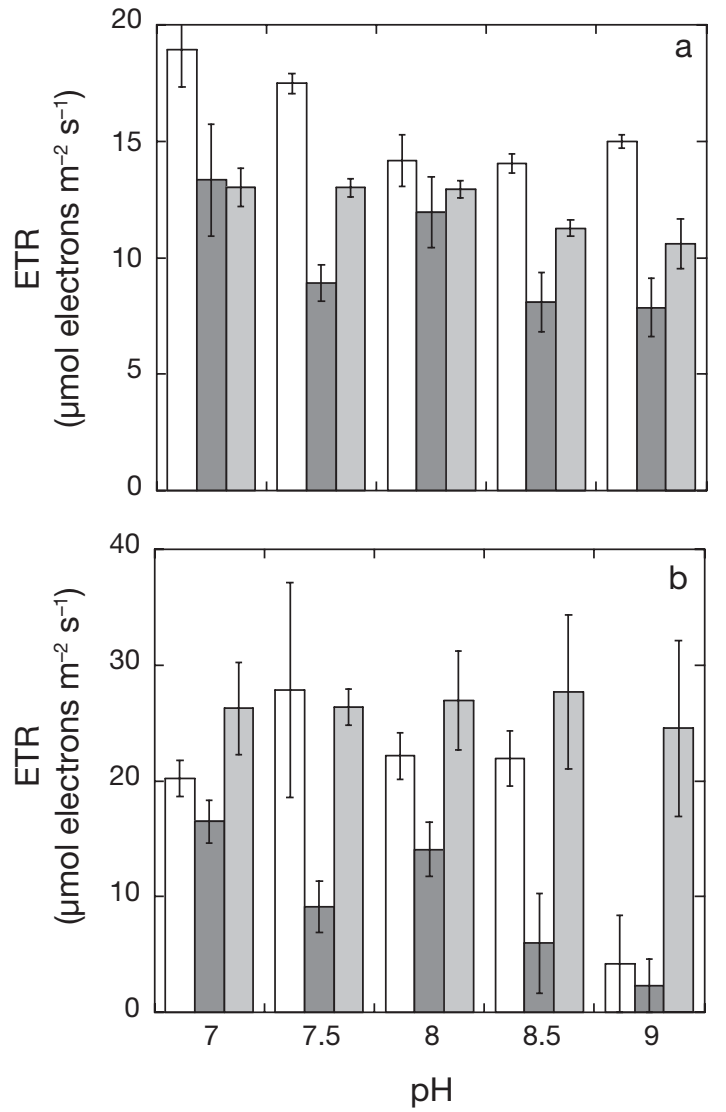

Fig. 5. Variation in the mean $( \pm \mathrm{SE})$ ETRs $\left(\mu \mathrm{mol}\right.$ electrons $\mathrm{m}^{-2}$ $\mathrm{s}^{-1}$ ) as a function of $\mathrm{pH}$ for Thalassia testudinum (white), Lobophora variegata (dark gray) and Padina sanctae-crucis (light gray) at: (a) subsaturating irradiance of $127 \mu$ mol quanta $\mathrm{m}^{-2} \mathrm{~s}^{-1}$ and (b) supersaturating irradiance of $1136 \mu \mathrm{mol}$ quanta $\mathrm{m}^{-2} \mathrm{~s}^{-1}$

After illuminating the photosynthetic tissue with $330 \mu \mathrm{mol}$ quanta $\mathrm{m}^{-2} \mathrm{~s}^{-1}$ for $4 \mathrm{~h}$, significant changes in ETRs were observed for the 3 species (data only shown for Thalassia testudinum; Fig. 6). Maximum values for the seagrass were, on average, 2.6 times higher after induction of photosynthesis, confirming the importance of the preliminary tissue illumination in the experimental design used in this study. A significant variation in ETRs along the T. testudinum leaf was also observed after the induction of photosynthesis. Maximum rates were 3 and 2.2 times higher at $5 \mathrm{~cm}$ and at $8 \mathrm{~cm}$ from leaf bases, respectively, than the control values obtained prior to leaf incubation (Fig. 6). Hence, the variability observed along the leaf was taken into account in the experimental design, and all of the experimental determinations on T. testudinum leaves were performed on the segment placed at $5 \mathrm{~cm}$ from the leaf base.

ETR values varied linearly with $\mathrm{O}_{2}$ evolution values only for the range of irradiances below, an average of $172 \mu \mathrm{mol}$ quanta $\mathrm{m}^{-2} \mathrm{~s}^{-1}(\mathrm{SE}=35.4, \mathrm{n}=12 ;$ Fig. 7$)$. The 


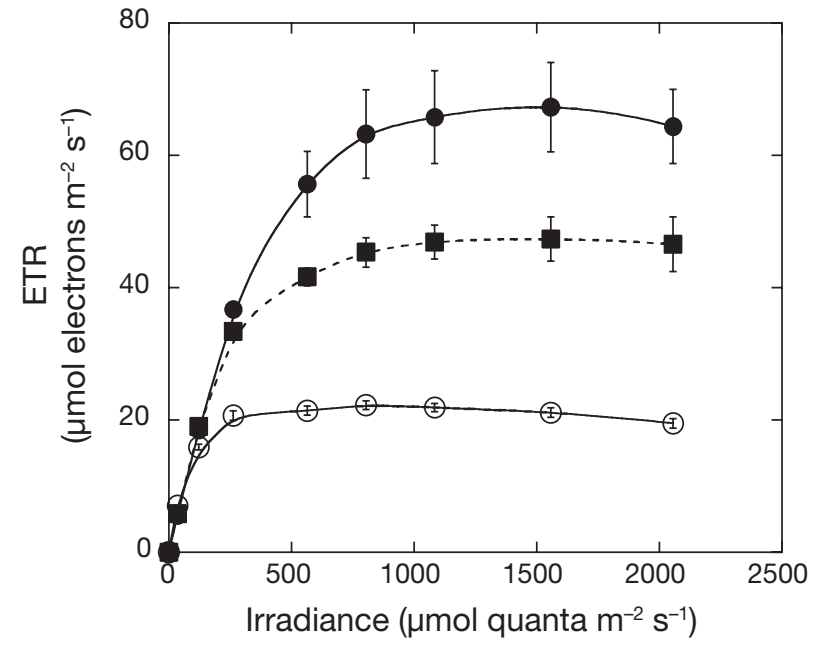

Fig. 6. Thalassia testudinum. Variation in the mean $( \pm \mathrm{SE})$ ETRs $\left(\mu \mathrm{mol}\right.$ electrons $\left.\mathrm{m}^{-2} \mathrm{~s}^{-1}\right)$ as a function of irradiance $(\mu \mathrm{mol}$ quanta $\mathrm{m}^{-2} \mathrm{~s}^{-1}$ ) for leaf segments (O): control values obtained before leaf incubation; (----): values of leaf segments at $8 \mathrm{~cm}$ from the leaf base after illuminating the leaf with $330 \mu \mathrm{mol}$ quanta $\mathrm{m}^{-2} \mathrm{~s}^{-1}$ for $4 \mathrm{~h}_{i}(\mathbf{O})$ : values at $5 \mathrm{~cm}$ from the leaf base after illumination

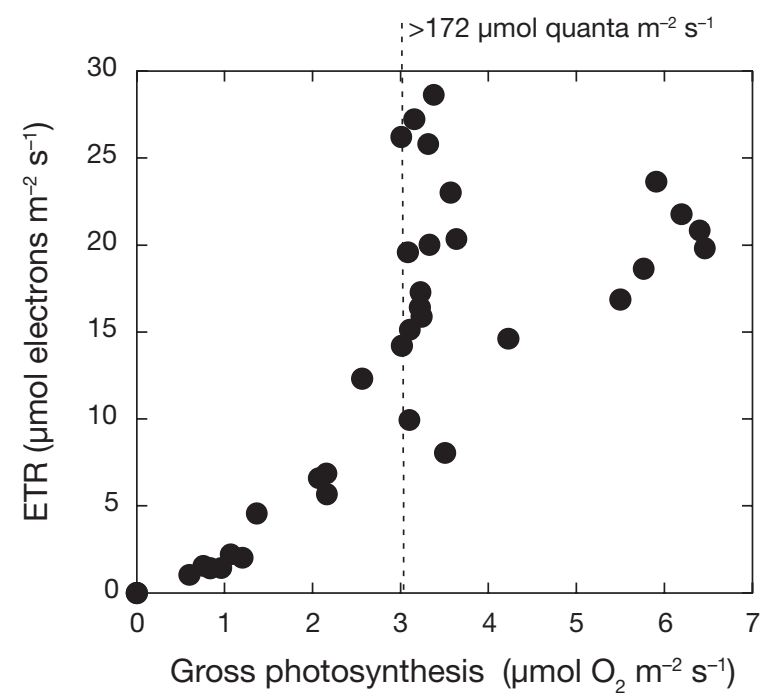

Fig. 7. Thalassia testudinum. Relationship between the photosynthetic rates measured as ETR ( $\mu$ mol electrons $\mathrm{m}^{-2} \mathrm{~s}^{-1}$ ) and oxygen evolution $\left(\mu \mathrm{mol} \mathrm{O}_{2} \mathrm{~m}^{-2} \mathrm{~s}^{-1}\right.$. Dotted line: average irradiance above which linearity is lost slope of this fit had a value of $3.9 \pm 0.3\left(R^{2}=0.91, p<\right.$ 0.01). An actinic light of $136 \mu \mathrm{mol}$ quanta $\mathrm{m}^{-2} \mathrm{~s}^{-1}$, which was close to the saturation irradiance $\left(E_{\mathrm{k}}\right)$ for the 3 species, was chosen to maintain the maximal ETR values within the linear range.

The 3 species examined exhibit significant declines in the effective photochemical efficiency $\left(\Delta F / F_{m}^{\prime}\right)$ at different water flow rates (Table 1). Thalassia testu-

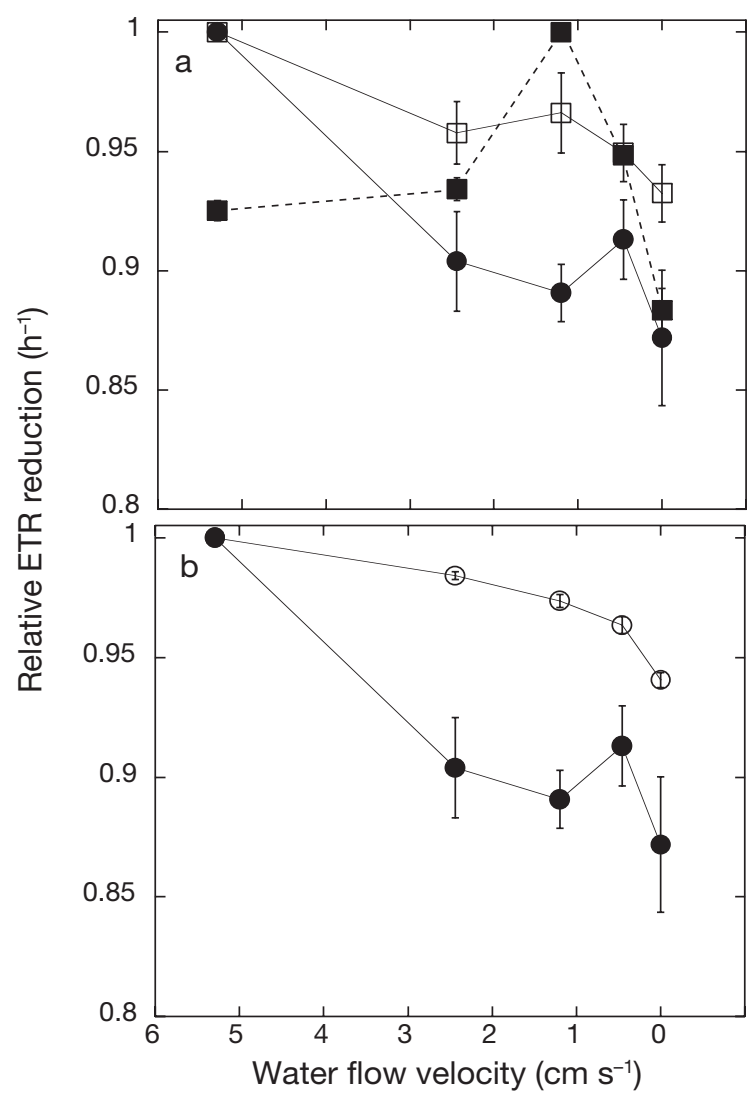

Fig. 8. Variation $( \pm \mathrm{SE})$ in the photosynthetic response (expressed as relative changes in $\mathrm{ETR}^{-1}$ ) as a function of the variation in the water flow velocity $\left(\mathrm{cm} \mathrm{s}^{-1}\right)$ for: (a) Thalassia testudinum (@), Lobophora variegata (---) and Padina sanctae-crucis ( $\square$ ) and (b) freshly collected leaves of T. testudinum (-) and leaves of $T$. testudinum maintained for $6 \mathrm{~d}$ at low water flow in the tanks of the Unidad Académica Puerto Morelos (O)

Table 1. Slope $( \pm \mathrm{SE})$ values of the variation of the effective photochemical efficiency of Photosystem II $\left(\Delta F / F_{\mathrm{m}}{ }^{\prime}\right)$ per minute, determined in different water flow regimes for the leaves of Thalassia testudinum acclimated for 1 and $6 \mathrm{~d}$ in the tanks of the UAPM facility, and for the thalli of Lobophora variegata and Padina sanctae-crucis acclimated for $1 \mathrm{~d}$ in the tanks

\begin{tabular}{|lcccc|}
\hline $\begin{array}{l}\text { Water flow } \\
\left(\mathrm{cm} \mathrm{s}^{-1}\right)\end{array}$ & $\begin{array}{c}\text { T. testudinum } \\
\text { 1 d tank acclimated }\end{array}$ & $\begin{array}{c}\text { T. testudinum } \\
\text { 6 d tank acclimated }\end{array}$ & $\begin{array}{c}\text { L. variegata } \\
\text { 1 d tank acclimated }\end{array}$ & $\begin{array}{c}\text { P. sanctae-crucis } \\
\text { d tank acclimated }\end{array}$ \\
\hline 5.29 & $0 \pm 0$ & $0 \pm 0$ & $-9.0 \times 10^{-4} \pm 0.7 \times 10^{-4}$ & $0 \pm 0$ \\
2.44 & $-9.1 \times 10^{-4} \pm 2.9 \times 10^{-4}$ & $-3.3 \times 10^{-4} \pm 0.5 \times 10^{-4}$ & $-7.9 \times 10^{-4} \pm 0.8 \times 10^{-4}$ & $-5.0 \times 10^{-4} \pm 2.2 \times 10^{-4}$ \\
1.2 & $-11.5 \times 10^{-4} \pm 2.8 \times 10^{-4}$ & $-4.5 \times 10^{-4} \pm 0.5 \times 10^{-4}$ & $0 \pm 0$ & $-4.0 \times 10^{-4} \pm 2.8 \times 10^{-4}$ \\
0.46 & $-9.6 \times 10^{-4} \pm 2.6 \times 10^{-4}$ & $-4.5 \times 10^{-4} \pm 0.6 \times 10^{-4}$ & $-6.2 \times 10^{-4} \pm 0.4 \times 10^{-4}$ & $-6.0 \times 10^{-4} \pm 2.0 \times 10^{-4}$ \\
0 & $-11.4 \times 10^{-4} \pm 3.9 \times 10^{-4}$ & $-7.4 \times 10^{-4} \pm 0.5 \times 10^{-4}$ & $-14.0 \times 10^{-4} \pm 1.5 \times 10^{-4}$ & $-8.0 \times 10^{-4} \pm 2.0 \times 10^{-4}$ \\
\hline
\end{tabular}


dinum and Padina sanctae-crucis showed no change in $\Delta F / F_{\mathrm{m}}{ }^{\prime}$ under the maximum flow of $5.3 \mathrm{~cm} \mathrm{~s}^{-1}$. At lower water velocities, both species showed a significant decline in ETR (Fig. 8a). As $\Delta F / F_{\mathrm{m}}{ }^{\prime}$ did not reach steadystate after $1 \mathrm{~h}$ of incubation, this decline was better expressed by calculating the relative ETR reduction observed after $1 \mathrm{~h}$ of incubation. No significant differences were found among the 4 water-flow treatments $\left(2.44,1.2,0.46\right.$ and $0 \mathrm{~cm} \mathrm{~s}^{-1}$ ) (ANOVA, p > 0.05; Fig. 8a). By contrast, Lobophora variegata showed optimal water flow for photosynthesis at $1.2 \mathrm{~cm} \mathrm{~s}^{-1}$. Below and beyond this value $L$. variegata exhibited significant reductions in $\Delta F / F_{\mathrm{m}}{ }^{\prime}, 1.6$ times higher under stagnant conditions than at the maximum flow of $5.3 \mathrm{~cm} \mathrm{~s}^{-1}$. The implications of these results for the ETR values are illustrated in Fig. 8. T. testudinum leaves showed, on average, a $10.5 \%$ reduction in ETRs after $1 \mathrm{~h}$ at $136 \mu \mathrm{mol}$ quanta $\mathrm{m}^{-2} \mathrm{~s}^{-1}$ under all water velocities lower than the maximum flow of $5.4 \mathrm{~cm} \mathrm{~s}^{-1}$. This effect was twice as great as the decline showed by $P$. sanctae-crucis (Fig. 8a), and similar to the response observed for stagnant conditions in L. variegata (Fig. 8a). L. variegata showed similar photosynthetic reductions to $P$. sanctae-crucis at low water velocity $\left(0.46 \mathrm{~cm} \mathrm{~s}^{-1}\right)$, and intermediate values to the other 2 species at $2.44 \mathrm{~cm} \mathrm{~s}^{-1}$.

Leaves of Thalassia testudinum collected from 2 different meadows (adjacent to the UAPM pier and close to the back-reef) did not show significant differences in their photosynthetic response to water flow (values not shown). Nevertheless, an interesting observation was found in the leaves of $T$. testudinum maintained for $6 \mathrm{~d}$ at low water flow at the UAPM facility (Fig. 8b). The significant progressive decline in the ETRs observed in the $6 \mathrm{~d}$ tank-acclimated leaves associated with the water flow reduction was less pronounced than the values observed in the leaves recently collected from the field (Fig. 8b). The $6 \mathrm{~d}$ acclimation to low water flow conditions at the UNAM facility allowed the leaves to reduce, on average, $63.5 \%$ of their photosynthetic sensitivity to water flow. Tankacclimated leaves were at optimal physiological conditions, as no significant differences were observed in the maximum photochemical efficiency after dark acclimation $\left(F_{\mathrm{v}} / F_{\mathrm{m}}=0.744 \pm 0.006\right)$, when compared with the freshly collected leaves. After photosynthesis induction, the
$\Delta F / F_{\mathrm{m}}{ }^{\prime}$ of the tank-acclimated leaves was even higher $(0.704 \pm 0.001)$ than the value previously obtained for recently collected leaves $(0.589 \pm 0.003)$.

The pharmacological experiments revealed significant interspecific differences in the effect of the inhibitors as well as a clear light-dependent effect (Fig. 9). No significant variation in the dark-adapted samples was found, with the exception of a small, but still significant, reduction in $F_{\mathrm{v}} / F_{\mathrm{m}}$ for Thalassia testudinum $(1.5 \%)$ and for Padina sanctae-crucis $(5.5 \%)$ in the Verapamil treatment (ANOVA, $\mathrm{p}<0.05$; Fig. 9a,e). Variation in $\Delta F / F_{\mathrm{m}}{ }^{\prime}$ was, however, highly significant. T. testudinum showed a 25, 31 and $50.5 \%$ reduction in $\Delta F / F_{\mathrm{m}}{ }^{\prime}$ with respect to the control treatment, for the
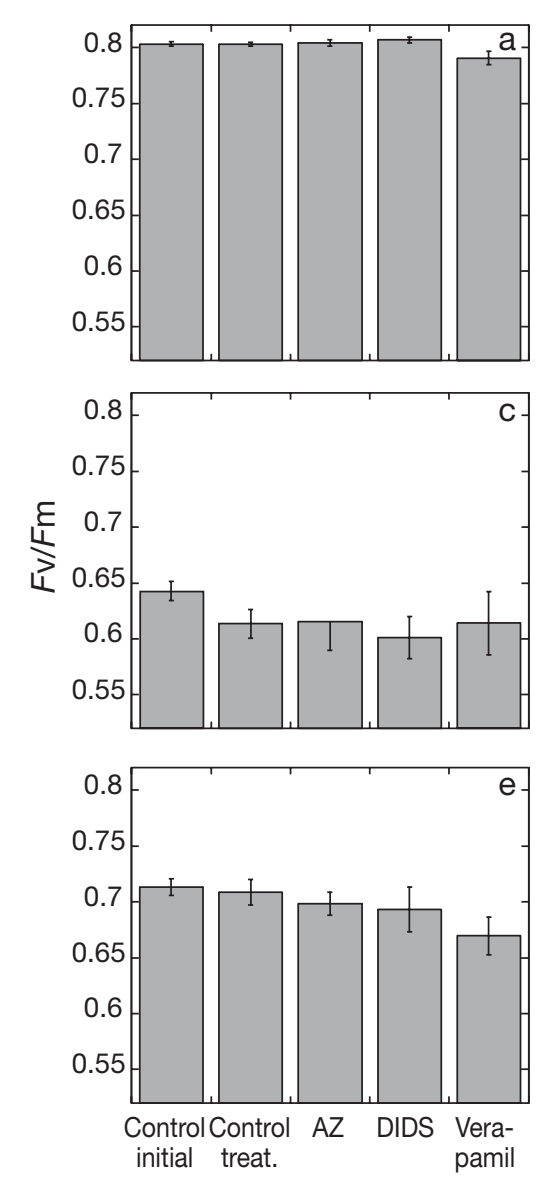

\section{Treatment}

Fig. 9. Means $( \pm \mathrm{SE})$ of the $(\mathrm{a}, \mathrm{c}, \mathrm{e})$ initial maximum photochemical efficiencies, $F_{\mathrm{v}} / F_{\mathrm{m}}$ and $(\mathrm{b}, \mathrm{d}, \mathrm{f})$ effective photochemical efficiency, $\Delta F / F_{\mathrm{m}}{ }^{\prime}$ variation observed in the tissue of $(\mathrm{a}, \mathrm{b})$ Thalassia testudinum, (c, d) Lobophora variegata and (e, f) Padina sanctae-crucis after being treated with: acetazolamide (AZ; N-[5-sulfamoyl-1,3,4-thiadiazol-2-yl] acetamide), an inhibitor of the extracellular activity of the enzyme carbonic anhydrase; the anion carrier inhibitor 4,48-diisothiocyanostilbene-2,28-disulfonic acid (DIDS); and the $\mathrm{Ca}^{2+}$ channel blocker Verapamil. A control treatment using filtered seawater was performed to check the effect on $\Delta F / F_{\mathrm{m}}$ ' of the syringe employed to infiltrate the inhibitors by means of moderate vacuum; Control initial: $F_{\mathrm{v}} / F_{\mathrm{m}}$ value before treatment; Control treat.: value after treatment 
addition of AZ, DIDS and Verapamil, respectively (ANOVA, $p<0.01$; Fig. 9b). Lobophora variegata only showed a significant response in the AZ treatment (31\% of reduction in $\Delta F / F_{\mathrm{m}}{ }^{\prime}$, ANOVA, $\mathrm{p}<0.01$; Fig. 9d). Finally, the photosynthesis of $P$. sanctae-crucis showed significant inhibitory effects with the addition of DIDS (31.6\% reduction, ANOVA, $\mathrm{p}<0.01)$ and Verapamil $(41.7 \%$, ANOVA, $\mathrm{p}<0.01)$, but no response with the addition of AZ (ANOVA, p > 0.05; Fig. 9f).

\section{DISCUSSION}

The initial experiment confirmed that photosynthesis in the seagrass Thalassia testudinum and the brown algae Lobophora variegata and Padina sanctae-crucis is sink limited at normal seawater $\mathrm{pH}$. The finding that the ETRs in T. testudinum and P. sanctae-crucis did not show any significant changes at supersaturating irradiance (Figs. 4a,c \& 5b) suggests that these 2 species have an efficient $\mathrm{CCM}$, probably related to $\mathrm{HCO}_{3}{ }^{-}$ uptake, as both species showed significant reductions in $\Delta F / F_{\mathrm{m}}{ }^{\prime}$ after the addition of the anion carrier inhibitor DIDS (Fig. 9b, f). T. testudinum leaves, however, showed the largest ETR decline under water flow reduction for the leaves recently collected from the field (Fig. 8a). Considering that the 3 species were acclimated to similar hydrodynamic regimes, we can conclude that the CCM of $T$. testudinum may be less efficient at seawater $\mathrm{pH}$ than that of $L$. variegata and P. sanctae-crucis. Nevertheless, we found a $63.5 \%$ reduction in the photosynthetic sensitivity of $T$. testudinum leaves to variation in hydrodynamics after being acclimated to low flow in the UAPM aquarium facility for $6 \mathrm{~d}$ (Fig. 8b). This result suggests that T. testudinum has a similar capacity to induce an efficient CCM.

$\beta$-carboxylation has been reported to be the main CCM in Thalassia testudinum (Benedict \& Scott 1976). These authors determined that the initial photosynthetic products are malic acid and aspartic acid, confirming a $\mathrm{C}_{4}$ pathway. Malate and aspartate together were not, however, the main early intermediates in the photosynthesis of its congeneric Indo-Pacific species T. hemprichii (Andrews \& Abel 1979). The importance of the enzyme CA to counterbalance carbon limitation in $T$. testudinum has also been suggested (Durako 1993). Its relative importance as a CCM in seagrasses has been tested in several species with contrasting results. Beer et al. (1980) found this enzyme to have a minimal contribution in T. hemprichii, Cymodocea nodosa and Thalassodendron ciliatum. However, a significant contribution for photosynthesis was observed in Zostera marina (Beer \& Rehnberg 1997), Posidonia australis (James \& Larkum 1996) and in the Mediter- ranean species Posidonia oceanica and Cymodocea nodosa (Invers et al. 1999). The relative importance of the enzyme CA versus the role of $\mathrm{HCO}_{3}{ }^{-}$uptake as the limiting factor of $T$. testudinum photosynthesis under natural environmental conditions still needs to be evaluated. In the present study, we found a significant $25 \%$ reduction in $\Delta F / F_{\mathrm{m}}$ ' after addition of the CA inhibitor AZ, and a $31 \%$ reduction for DIDS (Fig. 9b), indicative of the possibly relevant contribution of the enzyme CA to counterbalance carbon limitation in $T$. testudinum leaves. The highest effect $(50.5 \%)$ of the 3 inhibitors used here was found for the $\mathrm{Ca}^{2+}$ channel blocker Verapamil. Considering that calcium plays a major role in cell signaling, the addition of Verapamil may have induced other physiological processes, indirectly affecting photosynthesis.

In our analysis, Thalassia testudinum leaves did not show any ETR reduction when exposed to a water flow velocity of $5.3 \mathrm{~cm} \mathrm{~s}^{-1}$ and an actinic irradiance of $136 \mu \mathrm{mol}$ quanta $\mathrm{m}^{-2} \mathrm{~s}^{-1}$. The first photosynthetic decline was detected at $2.44 \mathrm{~cm} \mathrm{~s}^{-1}$ and resulted in a $10 \%$ reduction in ETR. No significant differences were observed between this treatment and the other $3(1.2$, 0.46 and $\left.0 \mathrm{~cm} \mathrm{~s}^{-1}\right)$. This result differs from the study by Koch (1994), who detected no effect of hydrodynamism on the photosynthesis of $T$. testudinum above a critical value of $0.25 \mathrm{~cm} \mathrm{~s}^{-1}$. Two possible explanations for this discrepancy may be found: (1) in the acclimatory capacity of $T$. testudinum photosynthesis to reduce sensitivity to a diminution or decrease in water velocity and (2) in the high sensitivity of the fluorescence technique to detect ETR declines, as the significant $\Delta F / F_{\mathrm{m}}{ }^{\prime}$ reductions estimated in this study ranged from 1.6 to $13.9 \%$ for incubations of $1 \mathrm{~h}$ at an actinic irradiance of $136 \mu \mathrm{mol}$ quanta $\mathrm{m}^{-2} \mathrm{~s}^{-1}$.

Lobophora variegata and Padina sanctae-crucis showed lower sensitivity to the reduction in the water flow than the recently collected leaves of Thalassia testudinum. This finding suggests the presence of efficient CCMs in both algal species. Both algae belong to the same family, Dictyotaceae, and share some common characteristics, such as blade shape. Algal shape will generate a thicker and more stable boundary layer than the flat, strip-like shape of seagrass leaves. The shape of both algal blades consists of convoluted blades with lobed margins covered by a coating of fine, short hairs. However, the CCM present in each algal species may not be similar. According to the pattern of variation found (Fig. 8a), ETRs in L. variegata were optimal at moderate water flow in accordance with the calm, shallow waters that this species prefers to colonize (Littler et al. 1989). This finding suggests that the CCM of $L$. variegata may be mediated by an external component and, thus, washed away at high water flow. This CCM may be the extracellular conversion of 
$\mathrm{HCO}_{3}^{-}$to $\mathrm{CO}_{2}$ mediated by the enzyme CA. The pharmacological experiment supported this conclusion as $L$. variegata showed a significant $\Delta F / F_{\mathrm{m}}{ }^{\prime}$ decline with the addition of AZ (Fig. 9d). The addition of the other 2 inhibitors did not produce any significant change on $\Delta F / F_{\mathrm{m}}{ }^{\prime}$. This result supports previous studies (Lucas 1983) that suggested possible negative effects of increasing current velocities on the photosynthesis of aquatic macrophytes due to CA cleansing.

The patterns of ETR variation as a function of water flow were similar in Padina sanctae-crucis and Thalassia testudinum. Nevertheless, the $\Delta F / F_{\mathrm{m}}{ }^{\prime}$ variation in $P$. sanctae-crucis showed lower sensitivity to the water flow (4.2 to $6.5 \%$ reduction between 2.4 and $0 \mathrm{~cm} \mathrm{~s}^{-1}$ ) than that in T. testudinum. P. sanctae-crucis inhabits areas with moderate hydrodynamics (Littler et al. 1989) and is commonly attached to rocks or dead coral heads. Such low sensitivity of $P$. sanctae-crucis photosynthesis to slow water flow confirms an adaptation to calm waters in this species due to the activity of an efficient CCM. The experiment with the inhibitors showed a significant $31.6 \%$ reduction in $\Delta F / F_{\mathrm{m}}{ }^{\prime}$ after the addition of the anion carrier (DIDS) and of $41.7 \%$ for the $\mathrm{Ca}^{2+}$ channel blocker Verapamil (Fig. 9f). Padina is the only calcifying brown algal genus (Littler et al. 1989). Its chalky white color results from the thin deposits of calcium carbonate on the upper blade surface. A large number of algal species in marine or freshwater environments have the ability to precipitate $\mathrm{CaCO}_{3}$, either as aragonite or calcite. These deposits can be biologically induced as a result of the interaction between the metabolic activity of the organism and the surrounding environment, or mediated by an organic matrix that may allow a strict biological control of the calcification process (Borowitzka 1989). Regardless of the type of calcification process, the deposition of $\mathrm{CaCO}_{3}$ crystals requires supersaturation and $\mathrm{CaCO}_{3}$ nucleation. The major metabolic mechanism in photosynthetic organisms that produces supersaturation of $\mathrm{CaCO}_{3}$ is inorganic carbon uptake for photosynthesis. $\mathrm{CO}_{2}$ uptake results in an increase in local $\mathrm{pH}$, and $\mathrm{HCO}_{3}{ }^{-}$uptake is usually coupled to $\mathrm{OH}^{-}$extrusion. Both mechanisms stimulate $\mathrm{CaCO}_{3}$ precipitation, and, therefore, calcification has been traditionally considered a secondary byproduct of photosynthesis (see Barnes \& Chalker 1990). Goreau (1963) was the first author to demonstrate that photosynthesis stimulates calcification in algae and corals. However, the mechanism or the diversity of mechanisms behind the coupling between photosynthesis and calcification is still controversial (see Gattuso et al. 2000). Padina deposits $\mathrm{CaCO}_{3}$ extracellularly on the surface of the tissue, as does Chara, in contrast to the extracellular precipitation within the intercellular spaces of Halimeda (Borowitzka \& Larkum 1987). Characean algae form acid and alkaline bands alternately on their cylindrical thallus. $\mathrm{CaCO}_{3}$ precipitation is promoted in the alkaline bands, and the protons generated during calcification are used for the $\mathrm{HCO}_{3}{ }^{-}$uptake in the acid band (McConnaughey 1991). According to this, calcification can also be considered, indirectly, as a CCM for characean algae and probably also for several other organisms, such as Padina spp. In the experiment with the inhibitors, P. sanctae-crucis showed significant ETR declines with the addition of Verapamil, both in darkness $(6 \%)$ and under illumination $(41.7 \%)$. Verapamil is a nonspecific inhibitor, and, as said before, many other physiological processes besides photosynthesis may have been affected after blocking $\mathrm{Ca}^{2+}$ channels. However, the distinct effect observed under illumination may suggest the presence of a mechanistic relation between calcification and photosynthesis in $P$. sanctaecrucis.

Our results revealed the high sensitivity of the fluorescence technique for the fast detection of changes in the photosynthetic response. The actinic light intensity chosen for the experimental design was $136 \mu \mathrm{mol}$ quanta $\mathrm{m}^{-2} \mathrm{~s}^{-1}$. This decision was made from the assumption that ETR estimations of $\mathrm{O}_{2}$ evolution rates are less accurate above a certain irradiance level, due to the increasing importance of mechanisms such as photorespiration (Wingler et al. 2000), cyclic electron flow (Joliot \& Joliot 2002), the Mehler reaction (Asada 2000) and PSII photoinhibition (Huner et al. 1998). A loss of linearity between oxygen-based and fluorescence-based determinations was found in the present study at relatively low irradiance values for the 3 species investigated (values only shown for Thalassia testudinum; Fig. 7). No significant photosynthetic response to carbon limitation would have been expected considering that the experimental light intensity used here was above the saturation irradiance $\left(E_{\mathrm{k}}\right)$ only for Lobophora variegata $\left(E_{\mathrm{k}}=81 \mu \mathrm{mol}\right.$ quanta $\left.\mathrm{m}^{-2} \mathrm{~s}^{-1}\right)$, close to the $E_{\mathrm{k}}$ value observed in T. testudinum (131 $\mu \mathrm{mol}$ quanta $\left.\mathrm{m}^{-2} \mathrm{~s}^{-1}\right)$ and below the $E_{\mathrm{k}}$ value found for Padina sanctae-crucis (176 $\mu \mathrm{mol}$ quanta $\mathrm{m}^{-2} \mathrm{~s}^{-1}$ ). However, we could detect small, but significant, variation in photosynthesis measured as the rate of change in $\Delta F / F_{\mathrm{m}}{ }^{\prime}$. We also found low induction of non-photochemical quenching (NPQ) in the water-flow experiments, as the values were in all cases $<0.4$ (NPQ for T. testudinum $=0.295 \pm 0.08$; NPQ for L. variegata $=0.260 \pm 0.01$; and NPQ for P. sanctaecrucis $=0.182 \pm 0.01$ ), confirming the low importance of the previously mentioned mechanisms, and supporting our selection of the actinic light intensity for the experimental set-up. Therefore, we concluded that, for the fluorescence technique to be suitable for the analysis of carbon limitation, the actinic experimental irradiance needs to be limited to values close to $E_{\mathrm{k}}$, where 
ETRs are maximal and the activation of alternative electron sinks to NADP reduction is minimal. Stronger declines, however, in the photosynthesis of the 3 species are expected under greater carbon requirements at supersaturating irradiance. Yet, the linearity between oxygen-based and fluorescence-based photosynthesis determinations imposes a strong limitation on the use of the fluorescence technique if the analysis is focused on the variation of the photosynthetic rates.

Our results also highlighted the importance of accurate light absorption determinations for achieving robust ETR estimations and molar ratios within the range imposed by the photosynthetic model. The present study study found a molar ratio of $3.9 \pm 0.29$, which corresponds to the theoretical minimum value predicted by the non-linear photosynthesis model of 4 electrons released by the PSII per $\mathrm{O}_{2}$ molecule evolved, supporting, therefore, the methodology employed here. The use of a constant absorptance value of 0.83 is an incorrect practice that may lead to erroneous conclusions in interspecific comparisons. Light absorption determinations require special methodological attention. The use of the integrating sphere for transmission and reflectance determinations is an option, but more accessible methodologies developed for dispersive samples, such as intact tissues, have been available for decades (i.e. Shibata 1959). The opal glass technique is not appropriate if surface reflectance (backscattering) is significant and/or proportionally larger than the sensitivity of the photomultiplier. A comparative study has shown the close compatibility of both methodologies (Enríquez et al. 1994) and that: (1) the opal glass technique, as expected, tends to overestimate light absorption due to the assumption that tissue reflectance is negligible and (2) the integrating sphere tends to underestimate absorptance due to a combination of 2 methodological errors (transmittance and reflectance determinations). The addition of both errors can be $>6$ to $10 \%$. Recently, a new method for measuring reflectance has been reported (Enríquez 2005, Enríquez et al. 2005). This method basically consists in the detection of reflected light at a certain angle $\left(45^{\circ}\right)$ using a waveguide attached to a spectrometer. This method is valid for samples not affected by specular reflexion, and allows for correction of the transmission values by subtracting tissue reflectance (Enríquez 2005), or the derivation of the equivalent absorbance spectrum, from the reflectance spectrum in opaque samples such as corals (Enríquez et al. 2005). Some of the alternative methodologies available in the literature for the determination of absorptance (often referred to by the incorrect term absorption factor) still wait for validation against a more robust method (i.e. Beer \& Bjørk 2000). Extremely low ETR values or molar ratios <4 (cf.
Maxwell \& Johnson 2000) may result from the use of incorrect absorptance estimations. To prevent this problem, the use of relative ETR values has been proposed (Beer et al. 2001), the use of which has progressively increased. Relative ETR values result from the multiplication of the effective photochemical efficiency $\left(\Delta F / F_{\mathrm{m}}^{\prime}\right)$ by a constant $(\mathrm{PAR} \times 0.5)$. The argument that relative ETR values can be used as an approximation of the rate of electrons pumped through the photosynthetic chain (Beer et al. 2001) is only correct if absorptance does not significantly contribute to the variation examined. As relative ETR is even more uncertain than the ETR values proposed by Genty et al. (1989) to describe the apparent rates of photosynthetic electron transport, its interpretation becomes less clear and may lead to erroneous conclusions in the variation of the photosynthetic capacity. For analysis of the variation in $\Delta F / F_{\mathrm{m}}$ ' between photosynthetic surfaces with significant differences in the optical cross section, information about the variation in the fraction of incident light absorbed by the photosynthetic membranes (i.e. absorptance) is a requirement. From our point of view, we recommend the use of ETR values only if reliable light absorption determinations are available. If not, the analysis should be restricted to the only variable examined: the effective photochemical efficiency of PSII $\left(\Delta F / F_{\mathrm{m}}{ }^{\prime}\right)$. Another important consideration highlighted in the present study is the importance of the correction for the spectrum of actinic light used. We found significant overestimation of the amount of incident light absorbed by the tissue (1.2 to 1.3 times), assuming homogeneous illumination throughout the PAR range. Small differences were observed between the 2 light sources used here. However, large differences are expected under field conditions if solar radiation is used as actinic light.

In summary, the results confirm that photosynthesis in Thalassia testudinum, Lobophora variegata and Padina sanctae-crucis is sink limited at normal seawater $\mathrm{pH}$. Two different patterns in the photosynthetic response to water flow were found. T. testudinum and $P$. sanctae-crucis showed photosynthetic optima at maximum water flow, with significant ETR declines below these values. By contrast, L. variegata showed optimum values at an intermediate water flow. Below and beyond a water flow optimum of $1.2 \mathrm{~cm} \mathrm{~s}^{-1}, L$. variegata exhibited significant ETR reduction. Stronger photosynthesis declines in the 3 species are expected under greater carbon requirements at supersaturating irradiance. The results suggest that photosynthesis may be strongly sink limited in sheltered, shallow, coral reef environments. Nevertheless, photosynthetic organisms adapted to these systems, in which calm, cloudless days with minimal water turbulence and maximum light penetration are common, have devel- 
oped efficient CCMs to reduce their photosynthetic sensitivity to carbon limitation in order to minimize carbon losses and PSII photodamage under saturating irradiance. These mechanisms are probably not very diverse, being basically related to: (1) the presence of the enzyme CA under very low hydrodynamics, when the diffusive boundary layer is stabilized and enzyme losses are minimal (e.g. L. variegata and T. testudinum) and (2) the ability to take up $\mathrm{HCO}_{3}^{-}$(e.g. T. testudinum and $P$. sanctae-crucis). The possibility that calcification could be associated with the CCM of $P$. sanctae-crucis still needs to be tested. The present study also supports the utility of the fluorescence technique for the analysis of photosynthetic responses to hydrodynamics within the limits imposed by the linearity between oxygen-based and fluorescence-based photosynthesis determinations. It also emphasizes the importance of light absorption determinations and the spectral description of the actinic light source utilized for the accurate estimations of ETR values.

Acknowledgements. This work was supported by a DGAPA grant (IN218599) from the Universidad Nacional Autónoma de México to S.E. We thank R. Iglesias-Prieto for his valuable support and helpful suggestions for the experimental development of this study, and the editorial assistance of P. Blanchon and A. T. Banaszak. E. Escalante-Mancera and F. G. Ruíz-Rentería from the UAPM Hydrographic and Meteorology Service are also acknowledged for enabling access to the water velocity database from the Puerto Morelos reef lagoon. Finally, the assistance of R. Álvarez-Gutierrez from the UAPM Library is acknowledged for his support in searching for literature. The experiments performed in this work comply with the current laws of Mexico.

\section{LITERATURE CITED}

Andrews TJ, Abel KM (1979) Photosynthetic carbon metabolism in seagrasses. ${ }^{14} \mathrm{C}$ labeling evidence for the $\mathrm{C}_{3}$ pathway. Plant Physiol 63:650-656

Asada K (2000) The water-water cycle as alternative photon and electron sinks. Philos Trans R Soc Lond B 355: 1419-1431

Barnes DJ, Chalker BE (1990) Calcification and photosynthesis in reef-building corals and algae. In: Dubinsky Z (ed) Ecosystems of the world. Coral reefs. Elsevier, Amsterdam, p 109-131

Beer S, Bjørk M (2000) Measuring rates of photosynthesis of two tropical seagrasses by pulse amplitude modulated (PAM) fluorometry. Aquat Bot 66:69-76

Beer S, Koch E (1996) Photosynthesis of marine macroalgae and seagrasses in globally changing $\mathrm{CO}_{2}$ environments. Mar Ecol Prog Ser 141:199-204

Beer S, Rehnberg J (1997) The acquisition of inorganic carbon by the seagrass Zostera marina. Aquat Bot 56:277-283

Beer S, Shomer-Ilan A, Waisel Y (1980) Carbon metabolism in seagrasses. II. Patterns of photosynthetic $\mathrm{CO}_{2}$ incorporation. J Exp Bot 31:1019-1026

Beer S, Bjørk M, Gademan R, Ralph PJ (2001) Measurements of photosynthesis in seagrasses. In: Short FT, Coles R (eds) Global seagrass research methods. Elsevier, Amsterdam, p 183-198

Benedict CR, Scott JR (1976) Photosynthetic carbon metabolism of a marine grass. Plant Physiol 57:876-880

Bjørk M, Haglund K, Ramazanov Z, García-Reina G, Pedersen $M$ (1992) Inorganic-carbon assimilation in the green seaweed Ulva rigida C. Ag. (Chlorophyta). Planta 187: $152-156$

Bjørk M, Weil A, Semesi S, Beer S (1997) Photosynthetic utilization of inorganic carbon by seagrasses from Zanzibar, East Africa. Mar Biol 129:363-366

Blank RJ (1987) Cell architecture of the dinoflagellate Symbiodinum sp. inhabiting the Hawaiian coral Montipora verrucosa. Mar Biol 94:143-155

Borowitzka MA (1982) Mechanisms in algal calcification. In: Round FE, Chapman DJ (eds) Progress in phycological research, Vol 1. Elsevier Biomedical Press, Amsterdam, p 137-177

Borowitzka MA (1989) Carbonate calcification in algae. Initiation and control. In: Mann S, Webb J, Williams RJP (eds) Biomineralization: chemical and biochemical perspectives. VCH, Weinheim, p 63-94

Borowitzka MA, Larkum AWD (1987) Calcification in algae: mechanisms and the role of metabolism. CRC Crit Rev Plant Sci 6:1-45

Bowes (1985) Pathways of $\mathrm{CO}_{2}$ fixation by aquatic organisms. In: Lucas WJ, Berry JA (eds) Inorganic carbon uptake by aquatic organisms. American Society of Plant Physiologists, Rockville, p 187-210

Drechsler Z, Beer S (1991) Utilization of inorganic carbon by Ulva lactuca. Plant Physiol 97:1439-1444

Durako MJ (1993) Photosynthetic utilization of $\mathrm{CO}_{2}$ and $\mathrm{HCO}_{3}{ }^{-}$in Thalassia testudinum (Hydrocharitaceae). Mar Biol 115:373-380

Enríquez S (2005) Light absorption efficiency and the package effect in the leaves of the seagrass Thalassia testudinum. Mar Ecol Prog Ser 289:141-150

Enríquez S, Agustí S, Duarte CM (1994) Light absorption by marine macrophytes. Oecologia 98:121-129

Enríquez S, Méndez ER, Iglesias-Prieto R (2005) Multiple scattering on coral skeleton enhances light absorption by symbiotic algae. Limnol Oceanogr 50:1025-1032

Gattuso JP, Reynaud-Vaganay S, Furla P, Romaine-Lioud S, Jaubert J (2000) Calcification does not stimulate photosynthesis in the zooxanthellate scleractinian coral Stylophora pistillata. Limnol Oceanogr 45:246-250

Genty B, Briantais JM, Baker NR (1989) The relationship between the quantum yield of photosynthetic electron transport and quenching of chlorophyll fluorescence. Biochim Biophys Acta 990:87-92

Giordano M, Maberly SC (1989) Distribution of carbonic anhydrase in British marine macroalgae. Oecologia 81: $534-539$

Goreau TF (1963) Calcium carbonate deposition by coralline algae and corals in relation to their role as reef-builders. Ann NY Acad Sci 109:127-167

Gutteridge S, Parry MAJ, Burton S, Keys AJ, Mudd A, Feeney J, Servaites JC, Pierce J (1986) A nocturnal inhibitor of carboxylation in leaves. Nature 324:274-276

Huner NPA, Øquist G, Sarhan F (1998) Energy balance and acclimation to light and cold. Trends Plant Sci 3:224-230

Invers O, Pérez M, Romero J (1999) Bicarbonate utilization in seagrass photosynthesis: role of carbonic anhydrase in Posidonia oceanica (L) Delile and Cymodocea nodosa (Ucria) Ascherson. J Exp Mar Biol Ecol 235:125-133

Invers O, Zimmerman RC, Alberte RS, Pérez M, Romero J (2001) Inorganic carbon sources for seagrass photosynthesis: an experimental evaluation of bicarbonate use in spe- 
cies inhabiting temperate waters. J Exp Mar Biol Ecol 265: 203-217

James PL, Larkum AWD (1996) Photosynthetic inorganic carbon acquisition of Posidonia australis. Aquat Bot 55: 149-157

Joliot P, Joliot A (2002) Cyclic electron transfer in plant leaf. Proc Natl Acad Sci USA 99:10209-10214

Keulen M van, Borowitzka MA (2000) Comparison of water velocity profiles through morphologically dissimilar seagrasses. Biol Mar Mediterr 7:143-146

Kirk JTO (1994) Light and photosynthesis in aquatic ecosystems, 2nd edn. Cambridge University Press, Cambridge

Koch EW (1994) Hydrodynamics, diffusion-boundary layers and photosynthesis of the seagrass Thalassia testudinum and Cymodocea nodosa. Mar Biol 118:767-776

Krause-Jensen D, Sand-Jensen K (1998) Light attenuation and photosynthesis of aquatic plant communities. Limnol Oceanogr 43:396-407

Larkum AWD, Roberts G, Kuo J, Strother S (1989) Gaseous movement in seagrasses. In: Larkum AWD, McComb AJ, Shepherd SA (eds) Biology of seagrasses. A treatise on the biology of seagrasses with special reference to the Australian region. Elsevier, New York, p 686-722

Littler DS, Littler MM, Bucher KE, Norris JN (1989) Marine plants of the Caribbean. A field guide from Florida to Brazil. Smithsonian Institution Press, Washington, DC

Lucas WL (1983) Photosynthetic assimilation of exogenous $\mathrm{HCO}_{3}$ by aquatic plants. Annu Rev Plant Physiol 34:71-104

Maberly SC (1990) Exogenous sources of inorganic carbon for photosynthesis by marine macroalgae. J Phycol 26: 439-449

MacFarlane JJ, Raven JA (1989) Quantitative determination of the unstirred layer permeability and kinetic parameters of Rubisco in Lemanea mamillosa. J Exp Bot 40: 321-327

Madsen TV, Sand-Jensen K (1991) Photosynthetic carbon assimilation in aquatic macrophytes. Aquat Bot 41:5-40

Editorial responsibility: Kenneth L. Heck Jr. (Contributing Editor), Dauphin Island, Alabama, USA
Maxwell K, Johnson GN (2000) Chlorophyll fluorescence-a practical guide. J Exp Bot 51:659-668

McConnaughey T (1991) Calcification in Chara corallina: $\mathrm{CO}_{2}$ hydroxylation gererates protons for bicarbonate assimilation. Limnol Oceanogr 36:619-628

Nowell ARM, Jumars PA (1984) Flow environments of aquatic benthos. Annu Rev Ecol Syst 15:303-328

Raven JA (1984) Energetics and transport in aquatic plants. Liss, New York

Raven JA, Osmond CB (1992) Inorganic C acquisition processes and their ecological significance in inter- and subtidal macroalgae of North Carolina. Funct Ecol 6:41-47

Raven JA, Richardson K (1986) Marine environments. In: Baker NR, Long SP (eds) Photosynthesis in contrasting environments. Elsevier Science Publishers, Berlin, p 337-398

Revsbech NP, Jørgensen BB (1983) Photosynthesis of benthic microflora measured with high spatial resolution by the oxygen microprofile method: capabilities and limitations of the method. Limnol Oceanogr 28:749-756

Shibata K (1959) Spectrophotometry of translucent biological materials: opal glass transmission method. Methods Biochem Anal 7:77-109

Smith RG, Bidwell RGS (1989) Mechanisms of photosynthetic carbon dioxide uptake by the red macroalga Chondrus crispus. Plant Physiol 89:93-99

Wheeler WN (1980) Effect of boundary layer transport on the fixation of carbon by the giant kelp Macrocystis pyrifera. Mar Biol 56:102-110

Wilkinson L (1989) SYSTAT: the system for statistics. SYSTAT, Evanston

Wingler A, Lea PJ, Quick WP, Leegood RC (2000) Photorespiration: metabolic pathways and their role in stress protection. Philos Trans R Soc Lond B 355:1517-1529

Zimmerman RC, Kohrs DG, Steller DL, Alberte RS (1997) Impacts of $\mathrm{CO}_{2}$ enrichment on productivity and light requirements of eelgrass. Plant Physiol 115:599-607

Submitted: November 24, 2004; Accepted: March 8, 2006

Proofs received from author(s): September 18, 2006 